A $\mathbf{C}$ G

Rec. Nat. Prod. $16: 5$ (2022) 477-482

records of natural products

\title{
Essential Oils of Lauraceae: Constituents and Antimicrobial Activity of Dehaasia cuneata (Blume) Blume and Caryodaphnopsis tonkinensis (Lecomte) Airy-Shaw from Vietnam
}

\section{Le Thi Huong ${ }^{1}$, Dao Thinh Minh Chau $\odot^{2}$, Do Ngoc Dai $\odot^{3,4 *}$ and Isiaka Ajani Ogunwande ${ }^{5 *}$}

\author{
${ }^{1}$ School of Natural Science Education, Vinh University, 182 Le Duan, Vinh City, Nghệ An Province \\ 4300, Vietnam \\ ${ }^{2}$ Institute of Biochemical Technology and Environment, Vinh University, 182 Le Duan, Vinh City, Nghệ An \\ Province, Vietnam \\ ${ }^{3}$ Graduate University of Science and Technology, Vietnam Academy of Science and Technology, \\ 18-Hoang Quoc Viet, Cau Giay, Hanoi, 10072, Vietnam \\ ${ }^{4}$ Faculty of Agriculture, Forestry and Fishery, NgheAn College of Economics, 51-Ly Tu Trong, Vinh City, \\ NgheAn Province, Vietnam \\ ${ }^{5}$ Foresight Institute of Research and Translation, Eleyele, Ibadan, Nigeria
}

(Received October 25, 2021; Revised December 12, 2021; Accepted December 17, 2021)

\begin{abstract}
The herbs, Dehaasia cuneata (Blume) Blume and Caryodaphnopsis tonkinensis (Lecomte) Airy-Shaw (Lauraceae) were used ethnomedically for the treatment of malaria, inflammation and amelioration of microbial infections. We report herein the chemical constituents and antimicrobial activity of the leaf essential oils of $D$. cuneata and $C$. tonkinensis from Vietnam. The technique of gas chromatography (GC) and gas chromatography coupled with mass spectrometry (GC/MS) was used to analyze the oil samples while the microdilution assay was employed to determine the antimicrobial efficacy. The main constituents of $D$. cuneata were $\alpha$-pinene $(49.0 \%)$, camphene $(19.5 \%), \beta$ pinene $(15.6 \%)$ and limonene (7.5\%), while $\alpha$-pinene (26.8\%), $\beta$-pinene $(23.0 \%)$ and bicyclogermacrene $(8.5 \%)$. The leaf oil of $D$. cuneata displayed potent antimicrobial activity against Gram-negative bacteria, Pseudomonas aeruginosa ATCC27853 with minimum inhibitory concentration (MIC) value of $5.37 \mu \mathrm{g} / \mathrm{mL}$; and Gram-positive microorganisms of Staphylococcus aureus ATCC25923 (MIC, $21.56 \mu \mathrm{g} / \mathrm{mL}$ and Bacillus cereus ATCC14579 (MIC, $23.45 \mu \mathrm{g} / \mathrm{mL}$ ). The leaf oil of $C$. tonkinensis exhibited good antibacterial activity towards Enterococcus faecalis ATCC299212 with MIC value of $15.99 \mu \mathrm{g} / \mathrm{mL}$, and anti-candidal action against Candida albicans ATCC10231 with MIC value of $33.68 \mu \mathrm{g} / \mathrm{mL}$. the chemical constituents and antimicrobial activity of the essential oils were being reported for the first time.
\end{abstract}

Keywords: Antimicrobial activity; essential oil composition; terpenes. (c) 2021 ACG Publications. All rights reserved.

\section{Plant Source}

Dehaasia cuneata Blume (syn. Cyanodaphne Blume) is known locally as Tiểu hoa nêm and normally used as culinary, spices and flavoring of foods and meats. The plant has been used in ethnomedicine for the

\footnotetext{
* Corresponding author: E-Mail: isiakaogunwande@gmail.com (I.A. Ogunwande); daidn23@gmail.com (D.N. Dai)
} 
Essential oil compositions and antimicrobial activity of D. Cuneata and C. tonkinensis

treatment of microbial infections and ulcers [1]. Caryodaphnopsis tonkinensis (Lecomte) Airy Shaw is a medium-sized tree often referred to in Vietnamese as Cà lồ bắc where it is used to treat microbial infections and act as spices in food condiments [2].

In the study, essential oils from the leaves of $D$. cuneata and $C$. tonkinensis collected Pù Mát National Park (GPS: $19^{\circ} 44^{\prime} 32^{\prime} \mathrm{N} ; 3^{\circ} 48^{\prime} 10^{\prime} \mathrm{E}$ ) and Bến En National Park (GPS: $19^{\circ} 35^{\prime} 31^{\prime} \mathrm{N} ; 105^{\circ} 22^{\prime} 59^{\prime} \mathrm{E}$ ), Vietnam, respectively, were analyzed by gas chromatography (GC) and gas chromatography-mass spectrometry (GC/MS) techniques, and then screened for antimicrobial efficacy.

\section{Previous Studies}

To the best of our knowledge, this is the first report on the chemical compositions and antimicrobial activities of essential oils from any parts of $D$. cuneata and $C$. tonkinensis grown in Vietnam or any other parts of the world. Moreover, no report could be seen on the volatile compositions and biological activities of other species in the genus Dehaasia and Caryodaphnopsis. However, a phytochemical study revealed that lupeol isolated from D. cuneata had a moderate inhibition on Serratia marcescens ATCC 14756 and low inhibition of Escherichia coli ATCC 25922, Vibrio fluvialis ATCC 33809, Bacillus subtilis ATCC 6633, and Methicillin-resistant Staphylococcus aureus ATCC 43300 [3]. Alkaloids were previously isolated from several Dehaasia species [4].

\section{Present Study}

The hydrodistillation of the leaves of $D$. cuneata produced light-yellow coloured essential oil. The average yield of essential oil was $0.35 \%$ (w/w). Figure 1 shows the chromatogram of the essential oils of $D$. cuneata.Table 1 presents the compounds as identified by GC/MS. Nineteen compounds accounting for $98.8 \%$ of the essential oil contents were identified in the leaves of $D$. cuneata. The composition of the essential oil was dominated by monoterpene hydrocarbon class of compounds $(95.9 \%)$. The sesquiterpene classes of compounds are less common in the essential oil (ca. $0.9 \%$ ). The main constituents of the essential oil were $\alpha$ pinene $(49.0 \%)$, camphene $(19.5 \%), \beta$-pinene $(15.6 \%)$ and limonene $(7.5 \%)$. Other compounds except myrcene $(2.9 \%)$ were identified in amount less than $1 \%$. On the other hand, 46 compounds representing 97.9\% of the essential oil contents were identified in the leaves of $C$. tonkinensis (Figure 2), while the yield obtained was $0.54 \%(\mathrm{w} / \mathrm{w})$. Monoterpene hydrocarbons $(71.3 \%)$, sesquiterpene hydrocarbons $(19.8 \%)$ and oxygenated sesquiterpenes $(56 \%)$ were the quantitatively significant classes of compounds present in the essential oil. The major constituents of the essential oil were $\alpha$-pinene $(26.8 \%), \beta$-pinene $(23.0 \%)$ and bicyclogermacrene $(8.5 \%)$. Other significant compounds of the essential oil were camphene $(4.9 \%)$, sabinene (4.1\%), limonene (3.3\%) and myrcene (3.2\%).

A comparative analysis of the present results with previously data on the essential oils of $D$. cuneata and $C$. tonkinensis could not be performed due to lack of information on the studied species or any other members in the studied genus. The chemical constituents of the essential oils of both D. cuneata and $C$. tonkinensis were being reported for the first time.

Table 1. Chemical compositions of the leaf essential oils of Dehaasia cuneata and Caryodaphnopsis tonkinensis collected in Vietnam

\begin{tabular}{|c|c|c|c|c|c|}
\hline \multirow[b]{2}{*}{ No } & \multirow[b]{2}{*}{ Compounds $^{\mathrm{a}}$} & \multirow[b]{2}{*}{$\mathbf{R I}^{\mathbf{b}}$} & \multicolumn{3}{|c|}{ Percent composition $^{d}$} \\
\hline & & & Range of RI $^{\mathrm{c}}$ & D. cuneata & C. tonkinensis \\
\hline 1 & Tricyclene & 928 & $909-922$ & 0.7 & - \\
\hline 2 & $\alpha$-Thujene & 930 & $921-939$ & - & 0.6 \\
\hline 3 & $\alpha$-Pinene & 939 & $924-941$ & 49.0 & 26.8 \\
\hline 4 & Camphene & 955 & $933-954$ & 19.5 & 4.9 \\
\hline 5 & Sabinene & 978 & $944-980$ & 0.4 & 4.1 \\
\hline 6 & $\beta$-Pinene & 984 & $964-985$ & 15.6 & 23.0 \\
\hline 7 & Myrcene & 992 & $981-993$ & 2.9 & 3.2 \\
\hline 8 & $\alpha$-Phellandrene & 1009 & $989-1011$ & - & 1.1 \\
\hline 9 & $\alpha$-Terpinene & 1021 & 1014-1024 & - & 1.0 \\
\hline
\end{tabular}


Huong et al., Rec. Nat. Prod. (2022) 16:5 477-482

\begin{tabular}{|c|c|c|c|c|c|}
\hline 10 & o-Cymene & 1030 & $1022-1034$ & 0.3 & 0.6 \\
\hline 11 & Limonene & 1035 & $1028-1038$ & 7.5 & 3.3 \\
\hline 12 & $\beta$-Phellandrene & 1036 & $1032-1040$ & - & 0.5 \\
\hline 13 & 1,8-Cineole & 1037 & $1032-1044$ & 0.7 & 0.3 \\
\hline 14 & $(E)$ - $\beta$-Ocimene & 1049 & $1041-1054$ & - & 0.3 \\
\hline 15 & $\gamma$-Terpinene & 1063 & $1042-1064$ & - & 1.3 \\
\hline 16 & Terpinolene & 1093 & $1071-1093$ & - & 0.6 \\
\hline 17 & Linalool & 1101 & $1098-1106$ & 0.1 & - \\
\hline 18 & $(E)-4,8$-Dimethylnona & & & & \\
\hline & -1,3,7-triene & 1117 & $1116-1120$ & - & 0.5 \\
\hline 19 & cis-Sabinol & 1148 & $1138-1152$ & 0.2 & - \\
\hline 20 & Terpinen-4-ol & 1185 & $1174-1206$ & - & 0.4 \\
\hline 21 & Myrtenol & 1204 & $1198-1212$ & 0.2 & - \\
\hline 22 & Myrtenal & 1206 & $1200-1218$ & 0.1 & - \\
\hline 23 & Sabinyl acetate & 1306 & $1289-1314$ & 0.5 & - \\
\hline 24 & Methyl genarate & 1326 & $1318-1344$ & 0.2 & - \\
\hline 25 & $\delta$-Elemene & 1347 & $1339-1354$ & - & 0.5 \\
\hline 26 & cis- $\beta$-Elemene & 1403 & $1385-1407$ & - & 0.2 \\
\hline 27 & $\beta$-Caryophyllene & 1437 & $1416-1448$ & 0.2 & 0.8 \\
\hline 28 & trans- $\alpha$-Bergamotene & 1445 & $1420-1450$ & - & 0.7 \\
\hline 29 & Aromadendrene & 1455 & $1437-1460$ & 0.1 & 1.5 \\
\hline 30 & Selina-5,11-diene & 1459 & $1444-1463$ & - & 0.2 \\
\hline 31 & $(E)$ - $\beta$-Farnesene & 1464 & $1452-1474$ & - & 0.2 \\
\hline 32 & $\alpha$-Humulene & 1471 & $1454-1488$ & - & 0.3 \\
\hline 33 & 9-epi-(E)-Caryophyllene & 1477 & $1458-1477$ & - & 0.2 \\
\hline 34 & $\alpha$-Zingiberene & 1502 & $1488-1510$ & - & 0.5 \\
\hline 35 & $\delta$-Selinene & 1504 & $1491-1518$ & - & 0.6 \\
\hline 36 & Bicyclogermacrene & 1513 & $1500-1520$ & - & 8.5 \\
\hline 37 & $\beta$-Bisabolene & 1517 & $1505-1523$ & - & 1.8 \\
\hline 38 & $\beta$-Curcumene & 1520 & $1520-1533$ & - & 0.2 \\
\hline 39 & $(Z)-\gamma$-Bisabolene & 1526 & $1522-1535$ & - & 1.7 \\
\hline 40 & $\beta$-Sesquiphellandrene & 1533 & $1532-1547$ & - & 0.3 \\
\hline 41 & $\delta$-Cadinene & 1535 & $1534-1540$ & - & 0.2 \\
\hline 42 & $(E)-\gamma$-Bisabolene & 1541 & $1537-1551$ & - & 0.9 \\
\hline 43 & (E)- $\alpha$-Bisabolene & 1550 & $1548-1558$ & - & 0.2 \\
\hline 44 & (E)-Nerolidol & 1569 & $1551-1569$ & - & 1.3 \\
\hline 45 & Germacrene B & 1576 & $1563-1580$ & - & 0.3 \\
\hline 46 & Palustrol & 1587 & $1569-1593$ & - & 0.2 \\
\hline 47 & Spathulenol & 1593 & $1571-1601$ & 0.5 & 1.6 \\
\hline 48 & Caryophyllene oxide & 1605 & $1578-1613$ & 0.1 & - \\
\hline 49 & Viridiflorol & 1602 & $1599-1612$ & - & 1.0 \\
\hline 50 & Cubeban-11-ol & 1612 & $1601-1618$ & - & 0.4 \\
\hline 51 & Rosifoliol & 1620 & $1620-1632$ & - & 0.2 \\
\hline 52 & $\beta$-Eudesmol & 1671 & $1647-1672$ & - & 0.4 \\
\hline 53 & $\alpha$-Eudesmol & 1672 & $1664-1684$ & - & 0.3 \\
\hline 54 & epi- $\alpha$-Bisabolol & 1696 & $1690-1702$ & - & 0.2 \\
\hline \multicolumn{4}{|c|}{ Total } & 98.8 & 97.9 \\
\hline & \multicolumn{3}{|c|}{ Monoterpene hydrocarbons } & 95.9 & 71.3 \\
\hline & \multicolumn{3}{|c|}{ Oxygenated monoterpenes } & 2.0 & 0.7 \\
\hline & \multicolumn{3}{|c|}{ Sesquiterpene hydrocarbons } & 0.3 & 19.8 \\
\hline & \multicolumn{3}{|c|}{ Oxygenated sesquiterpenes } & 0.6 & 5.6 \\
\hline & \multicolumn{3}{|l|}{ Non-terpenes } & - & 0.5 \\
\hline
\end{tabular}

a Elution order on HP-5MS column; ${ }^{b}$ Experimental retention indices; ${ }^{\mathrm{c}}$ Range of LRI Literature retention indices on HP-5MS column as seen in NIST [5]; ${ }^{\mathrm{d}}$ means of three replicate values, SD ( \pm ) omitted to avoid congestion; Sr. No, serial number; - not identified 
Essential oil compositions and antimicrobial activity of D. Cuneata and C. tonkinensis

Essential oils from the leaves of both $D$. cuneata and $C$. tonkinensis displayed antimicrobial activity towards five of the tested microorganisms, and anti-candidal activity with varying MIC values in the range of $5.0-60.0 \mu \mathrm{g} / \mathrm{mL}$ (Table 2). The leaf oil of D. cuneata displayed potent antimicrobial activity against Gramnegative bacteria, $P$. aeruginosa ATCC27853 with MIC value of $5.37 \mu \mathrm{g} / \mathrm{mL}$. Moreover, the essential oil showed notable activity towards the Gram-positive microorganisms of $S$. aureus ATCC25923 (MIC, 21.56 $\mu \mathrm{g} / \mathrm{mL}$ and B. cereus ATCC14579 (MIC, $23.45 \mu \mathrm{g} / \mathrm{mL}$ ). However, D. cuneata leaf oil exhibited lesser inhibitory anti-candidal activity to $C$. albicans ATCC10231 with MIC value of $56.56 \mu \mathrm{g} / \mathrm{mL}$. The leaf essential oil of $D$. cuneata exhibited higher antibacterial action than the non-volatile lupeol which has low inhibition of B. subtilis and S. aureus [3]. However, lupeol [3] was more active against E. coli than the essential oil. On the other hand, the leaf oil of $C$. tonkinensis exhibited good antibacterial activity towards $E$. faecalis ATCC299212 with MIC value of $15.99 \mu \mathrm{g} / \mathrm{mL}$, and anti-candidal action against $C$. albicans ATCC10231 with MIC value of $33.68 \mu \mathrm{g} / \mathrm{mL}$. Also, the essential oil showed lesser antimicrobial action towards S. aureus ATCC25923 (MIC, $56.78 \mu \mathrm{g} / \mathrm{mL}$ ), B. cereus ATCC14579 (MIC, $56.54 \mu \mathrm{g} / \mathrm{mL}$ ) and $P$. aeruginosa ATCC27853 (MIC, $57.78 \mu \mathrm{g} / \mathrm{mL}$ ). On the whole, the leaf oil of D. cuneata showed greater antimicrobial potential, with lower MIC values than the leaf oil of $C$. tonkinensis. Conversely, the leaf oil of C. tonkinensis exhibited twice greater anti-candidal action than the leaf oil of D. cuneata.

Table 2. Antimicrobial activity of Dehaasia cuneata and Caryodaphnopsis tonkinensis leaves essential oils

\begin{tabular}{lllll}
\hline & \multicolumn{2}{c}{ MIC $(\boldsymbol{\mu g} / \mathbf{m L})^{\mathbf{a}, \mathbf{b}, \mathbf{c}, \mathbf{d}}$} & \multicolumn{2}{c}{$\mathbf{I C}_{\mathbf{5 0}}(\boldsymbol{\mu g} / \mathbf{m L})^{\mathbf{a}}$} \\
\hline Microorganisms & D. cuneata & C. tonkinensis & D. cuneata & C. tonkinensis \\
\hline Enterococcus faecalis ATCC299212 & 16.72 & 15.99 & 32.0 & 32.0 \\
Staphylococcus aureus ATCC25923 & 21.56 & 56.78 & 64.0 & 128.0 \\
Bacillus cereus ATCC14579 & 23.45 & 56.54 & 64.0 & 128.0 \\
Escherichia coli ATCC 25922 & - & - & - & - \\
Pseudomonas aeruginosa ATCC27853 & 5.37 & 57.78 & 16.0 & 128.0 \\
Salmonella enterica ATCC13076 & - & - & - & - \\
Candida albicans ATCC 10231 & 65.56 & 33.68 & 128.0 & 64.0 \\
\hline
\end{tabular}

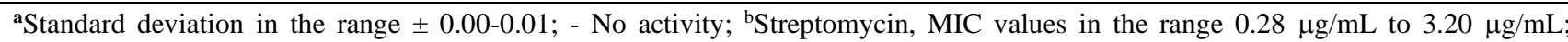
${ }^{\mathrm{C}}$ Nystatine MIC value of $8.0 \mu \mathrm{g} / \mathrm{mL} ;{ }^{\mathrm{d}}$ Cycloheximide MIC value of $3.20 \mu \mathrm{g} / \mathrm{mL}$.

The MIC and $\mathrm{IC}_{50}$ values provided evidence that the leaf essential oils of both D. cuneata and $C$. tonkinensis displayed potent antimicrobial and anti-candidal activities against the tested microorganisms except E. coli ATCC 25922 and S. enterica ATCC13076. Recent findings indicated that substances with MIC values $\leq 100 \mu \mathrm{g} / \mathrm{mL}$ may be considered to be of good antimicrobial activity [6]. Thus, D. cuneata and $C$. tonkinensis essential oils should be considered a promising antimicrobial agent because the essential oil displayed antibacterial activity with most MIC $<100 \mu \mathrm{g} / \mathrm{mL}$. Streptomycin, the standard antimicrobial agent for gram-positive bacteria displayed antimicrobial activity with MIC values in the range $0.28 \mu \mathrm{g} / \mathrm{mL}$ to 3.20 $\mu \mathrm{g} / \mathrm{mL}$. In addition, nystatine used as standard antimicrobial agent had MIC value of $8.0 \mu \mathrm{g} / \mathrm{mL}$, with cycloheximide, an anti-candidal agent, showing activity at MIC of $3.20 \mu \mathrm{g} / \mathrm{mL}$. This is the first report on the antimicrobial activity of essential oils of $D$. cuneata and $C$. tonkinensis.

The antimicrobial activities of the essential oils of D. cuneata and $C$. tonkinensis can be related to their main constituents or some synergy between the major and minor compounds. Essential oil constituents were previously reported to inhibit significantly the growth and cell viability of potential infectious of broad spectrum microorganisms. Nevertheless, the antibacterial effect can be sum up as cumulative actions of several compounds and not to a specific compound [7-11]. Further, due to the complexity of the composition of the essential oils, it is also difficult to explain the mechanism of action of these blends, but is important to underline that the wide variety of composition is a positive factor that may limit the development of resistance which is otherwise very common for synthetic drug. The major constituents of essential oils D. cuneata and $C$. tonkinensis such as $\alpha$-pinene and $\beta$-pinene have shown antimicrobial activity against infection causing microorganisms such as $S$. aureus [12,13]. Essential oil with large contents of bicyclogermacrene and germacrene $\mathrm{D}$ have displayed antimicrobial activity against organisms such as $P$. aeruginosa, $C$. albicans and $S$. aureus with MIC value of $125 \mathrm{mg} / \mathrm{mL}$ [14], as well as B. cereus and E. coli with MIC value of $64 \mu \mathrm{g} / \mathrm{mL}$ [15]. Limonene and camphene were reported to exhibit moderate antimicrobial action against $E$. faecalis, $S$. 
Huong et al., Rec. Nat. Prod. (2022) 16:5 477-482

aureus, B. cereus and C. albicans [16]. The antimicrobial activities of some other compounds present in the essential oils have been reported [7-11, 17], and likely to account for the observed antimicrobial activity.

\section{Acknowledgments}

We are grateful to Mrs. Musilmat Buhari for the typesetting of the manuscript to our satisfaction.

\section{Supporting Information}

Supporting Information accompanies this paper on http://www.acgpubs.org/journal/records-ofnatural-products

\section{ORCID}

Le T. Huong: 0000-0003-1123-2037

Dao T.M. Chau 0000-0002-0585-2750

Do. N. Dai 0000-0002-7741-9454

Isiaka A. Ogunwande: 0000-0002-5423-887X

\section{References}

[1] H.V. Sam, K. Nanthavong and P.J.A. Kesler (2004). Trees of Laos and Vietnam: A field guide to 100 economically or ecologically important species, Blumea. 49, 210-349.

[2] T.V. Nguyen, R. Mitlohner, N.V. Bich and T.V. Do (2015). Environmental factors affecting the abundance and presence of tree species in a tropical lowland limestone and non-limestone forest in Ben En National Park, Vietnam, J. For. Environ. Sci. 31,177-191.

[3] R.R. Andi, S.O.I. Sumail, S. Noor Aziiraa, W.A. Wan Yaacob and L.M.R. Al Muqarrabun (2021). Antibacterial activity of lupeol from the bark of Dehaasia cuneate (Lauraceae), Curr. Res. Biosci. Biotechnol. 2, 145-148.

[4] W.M.N.H. Wan Salleh and F. Ahmad (2017). Alkaloids from the genus Dehaasia; phytochemistry and biological activities, J. Appl. Pharm. Sci.7, 207-211.

[5] National Institute of Science and Technology (2018). Chemistry Web Book. Data from NIST Standard Reference Database 69.

[6] F.B. Holetz, G.L. Pessini, N.R. Sanches, D.A.G. Cortez, C.V. Nakamura and B.P. Dias-Filho (2002). Screening of some plants used in the Brazilian folk medicine for the treatment of infectious diseases, Mem. Inst. Oswaldo Cruz. 97, 1027-1031.

[7] L.T. Huong, N.T. Chung, D.T.M. Chau, D.N. Dai and I.A. Ogunwande (2021). Annonaceae essential oils: antimicrobial and compositions of the leaves of Uvaria hamiltonii Hook. f. \& Thoms. and Fissistigma kwangsiensis Tsiang \& P. T. Li, Rec. Nat. Prod. (in press). Doi: doi.org.10.25135/rnp.281.2018-2161.

[8] N.T. Nhan, C.T. Lan, L.D. Linh, L.T. Huong, D.N. Dai, D.N. and I.A. Ogunwande (2021). Chemical compositions of essential oils and antimicrobial activity of Alpinia kwangsiensis from Vietnam, J. Essent. Oil Bearing Plants. 24, 714-723.

[9] N.A. Dung, L.T. Huong, D.N. Dai and I.A. Ogunwande. (2021). The leaf essential oil of Acorus macrospadiceus (Yam.) F. N. Wei \& Y. K. Li from Vietnam: chemical composition and antimicrobial activity, J. Essent. Oil Bearing Plant. 24, 745-752.

[10] L.T. Huong, L.N. Sam, B.D. Thach, D.N. Dai and I.A. Ogunwande (2021) Chemical compositions of essential oils and antimicrobial activity of Amomum cinnamomeum from Vietnam, Chem. Nat. Compd. 57, 574-577.

[11] L.T. Huong, N.T. Viet, L.Y. Sam, C.N. Giang, N.H. Hung, D.N. Dai and I.A. Ogunwande (2021) Antimicrobial activity of the essential oils from the leaves and stems of Amomum rubidum Lamxay \& N. S. Lý, Bol. Latinoam. Caribe Plant. Med. Aromát. 20, 81-89.

[12] Y. Asakawa (2021). Dietary monoterpenoids. In. Handbook of Dietray Phytochemicals. (J. Xiao, S. Sarker and Y. Asakawa eds.). Springer, Singapore, vol. 2, pp. 607.

[13] A.M. Leite, E.O. Lima, E.L. Souza, M. Dinz, V.N. Trajano and I.A. Medeiros (2007). Inhibitory effect of $\alpha-$ pinene and $\beta$-pinene and eugenol on the growth of potential infectious causing gram-positive bacteria, Braz. J. Pharm. 43, 121-126.

[14] N. Tabanca, F. Demirci, T. Ozek, G. Tumen and K.H.C. Baser (2001). Composition and antimicrobial activity of the essential oil of Origanum $\times$ dolichosiphon P. H. Davis, Chem. Nat. Compd. 37, 238-241. 
Essential oil compositions and antimicrobial activity of D. Cuneata and C. tonkinensis

[15] F.G.R. Fabiola, G.S.O. Liana, F.G.R. Fabio, E.S. Manuele, S.C.X. Almeida, M.E.S. Cabral, A.R. Campos and J.G.M. Costa (2012). Chemical composition, antibacterial and antifungal activities of essential oil from Cordia verbenaceaea DC leaves, Pharmcog. Res. 4, 161-165.

[16] A. DeCarlo, T. Zeng, N.S. Dosoky, P. Satyal and W.N. Setzer (2020). The essential oil composition and antimicrobial activity of Liquidambar formosana oleoresin, Plants 9, 822-832.

[17] G. Lang and G. Buchbaeur (2012). A review on recent research results (2008-2010) on essential oils as antimicrobials and antifungals, Flav. Fragr. J. 27, 13-39.

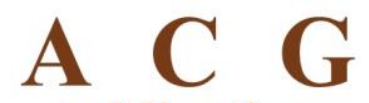

publications

(C) 2021 ACG Publications 